\title{
ISTOTA REFORMY ROLNEJ W II RZECZYPOSPOLITEJ
}

\begin{abstract}
Streszczenie
Ustawa z 1920 roku przewidywała parcelację przymusową majątków ziemskich i przekazywanie ziemi chłopom za połowę ceny rynkowej. Przeszkodą w jej realizacji stał się zapis w konstytucji z 1921 roku o nienaruszalności własności prywatnej. Dopiero ustawa z 1925 roku, przewidująca sprzedaż rozparcelowanej ziemi po cenie rynkowej, mogła być uznana za zgodną z konstytucją.

Dwa zasadnicze czynniki warunkowaly realizację reformy rolnej, poczynając od 1926 roku - cena ziemi i popyt na ziemię. Profesor Witold Staniewicz, kierując Ministerstwem Reform Rolnych w latach 1926-1930, nadał reformie charakter dwuczłonowy: obok parcelacji majątków, intensywnie była prowadzona komasacja ziemi w gospodarstwach chłopskich. Parcelację traktował on jako czynnik skłaniający mieszkańców wsi do przestrzennego uporządkowania gruntów. Reforma miała być długotrwałym procesem parcelacji majątków i komasacji ziemi chłopskiej. Można ją porównać z reformą uwłaszczeniową w zaborze pruskim w XIX wieku. Istota reformy rolnej w II Rzeczypospolitej polegała na wzmacnianiu gospodarstw rodzinnych w dłuższej perspektywie. Temu służyła ziemia z rozparcelowanych majątków oraz komasacja ziemi we wsiach.
\end{abstract}

Słowa kluczowe: II Rzeczypospolita, reforma rolna, Witold Staniewicz

\section{AGRARIAN REFORM IN SECOND POLISH REPUBLIC}

\section{Summary}

The Act of 1920 provided for compulsory subdivision of estates and transfer of land to the peasantry at half the market price. An obstacle to the implementation of the law was the constitutional clause of the inviolability of private property passed in 1921. It was only the Act of 1925, providing for the sale of land at market price, that was deemed to be compatible with the Constitution.

Two essential factors influenced the implementation of the agrarian reform of 1926: the price of land and the demand for land. Professor Witold Staniewicz, the Minister of Agrarian Reform in the years 1926-1930, divided the reform into two stages: besides the breaking up of estates, intense accumulation of land in peasant farms was undertaken. He regarded the subdivision of estates as a factor conducive to the change of spatial arrangement of lands. The reform was to involve a lengthy process of parcellation of estates and land regrouping. It is possible to compare it with the reform of enfranchisement in the Prussian Partition in the nineteenth century. The essence of the land reform in the Second Polish Republic was a long-term strengthening of family farms.

Key words: Second Polish Republic, agrarian reform, Witold Staniewicz

JEL: N, Q 


\section{Wstęp}

Wiek powstawania i rozwoju przemysłu był dla Polaków w znacznej mierze wiekiem utraconym. Tylko w Królestwie Polskim rozwinął się przemysł, zaś na pozostałym obszarze ziem polskich dominowała stagnacja. Zaborca pruski traktował Wielkopolskę i Kujawy jako zaplecze rolnicze Berlina oraz innych ośrodków przemysłowych Prus. Austria była obojętna na nędzę tzw. Galicji i nie wykazywała inicjatywy w zakresie rozwoju gospodarczego tej prowincji. Podobny był stosunek Rosji do zabranych przez nią ziem polskich. Jedynie w Królestwie Polskim dzięki autonomii powstały warunki sprzyjajace uprzemysławianiu.

Druga Rzeczypospolita to już nie Rzeczypospolita szlachecka, a początek współczesnej Polski i trudny poczatek po 123 latach niewoli. Wielu fascynuje młodość społeczeństwa Polski Odrodzonej, romantyzm budowanej Gdyni, determinacja reformy pieniężnej, jednak warto także zwrócić uwagę na realizm rozpoczętej wówczas reformy rolnej.

\section{Założenia i przebieg reformy}

W Polsce Odrodzonej przeważała ludność związana z rolnictwem, natomiast rolnictwo było podstawowym źródłem utrzymania dla większości obywateli II Rzeczypospolitej. Stąd problemy występujące w rolnictwie nie mogły być pomijane i Sejm Rzeczypospolitej już w pierwszym roku swojej działalności obradował nad kwestią reformy rolnej. Podjęto wówczas uchwałę o reformie zmierzającej do poprawy struktury agrarnej, zaś w roku następnym przyjęto ustawę o podobnej treści. Ustawa z 1920 roku przewidywała parcelację przymusową majątków ziemskich i sprzedaż chłopom ziemi uzyskanej w ten sposób za połowę ceny rynkowej. Jednakże przeszkodą w realizacji tego zapisu ustawowego stał się zapis w konstytucji z 1921 roku o nienaruszalności własności prywatnej. Dopiero nowa ustawa o reformie rolnej, przyjęta pod koniec 1925 roku, przewidywała sprzedaż ziemi z parcelacji według ceny rynkowej i mogła być uznana przy określonej interpretacji - za zgodną z konstytucja.

Poczynając od roku 1926, dwa czynniki warunkowały parcelację majątków, a mianowicie cena ziemi oraz popyt na ziemię ze strony rolników uprawnionych do nabywania ziemi z parcelacji. Ministerstwo Reform Rolnych i podległe mu urzędy ziemskie, prowadząc przymusowa parcelację majątków, mogły w jakimś stopniu przyczynić się do obniżenia ceny ziemi, lecz jeżeli popyt byłby niewystarczający w stosunku do podaży, to napotkałyby barierę ograniczająca przebieg reformy. Świadczy o tym zahamowanie reformy w latach wielkiego kryzysu gospodarczego.

W ustawie z 1925 roku umieszczono kontyngent parcelacyjny w wysokości 200 tys. ha rocznie [Ustawa z dnia 28 grudnia 1925 roku..., 1926, art. 11]. Wielkość ta miała charakter motywacyjny, bowiem aktywizowała aparat wykonawczy do parcelacji majątków, o ile popyt na ziemię z parcelacji był zadowalający. Wówczas należało prowadzić parcelację aż do wykonania kontyngentu, zaś niewykonana część kontyngentu w danym roku miała być rozparcelowana w roku następnym poza kontyngentem. Natomiast gdy popyt na ziemię był mały, to aparat wykonawczy związany z reformą musiał rezygnować 
z przymusowej parcelacji, mimo niewykonania kontyngentu, gdyż dobrowolna parcelacja majątków zaspokajała popyt na ziemię. Roczny kontyngent parcelacyjny obejmował parcelację przymusową i dobrowolną.

Obok kontyngentu i jego motywacyjnej roli, występowały także ograniczenia zapisane w ustawie. Ziemia rozparcelowana mogła znajdować się w gestii Ministerstwa Reform Rolnych lub Banku Rolnego przez rok, ale nie dłużej. Zatem dopuszczalna była tylko roczna administracja tej ziemi, a najpóźniej, po roku, ziemia musiała być sprzedana zgodnie z przeznaczeniem [Ustawa z dnia 28 grudnia 1925 roku..., 1926, art. 15]. Nabywcami mogli być tylko rolnicy nowo tworzonych lub powiększanych gospodarstw, a powierzchnia tych gospodarstw nie mogła przekraczać 20 ha. Tylko w województwach wschodnich i w województwie białostockim, jak również w powiatach górskich powierzchnia gospodarstw, powstających w wyniku reformy oraz powiększanych dzięki reformie, mogła dochodzić do 35 ha, nie przekraczając tej granicy [Ustawa z dnia 28 grudnia 1925 roku..., 1926, art. 50].

W pierwszych latach funkcjonowania ustawy z 1925 roku kontyngent parcelacyjny był przekraczany [Mały Rocznik Statystyczny, 1939, s. 70], ponieważ występował wówczas duży popyt na ziemię, kształtowany dobrą koniunktura. Tymczasem w latach kryzysu gospodarczego gwałtownie zmalała parcelacja majątków: w roku 1933 rozparcelowano w skali kraju tylko 83 tys. ha, zaś w 1934 roku - zaledwie 56 tys. ha. Stało się to za sprawą niskiego poziomu dochodów w rolnictwie. Przeciętny przychód z produkcji towarowej w gospodarstwach , rachunkowiczów” był w roku 1934-35 na poziomie 37\% wielkości przychodu osiaganego w roku gospodarczym 1927-28 [Noniewicz, 1996, s. 42]. Przy niskich dochodach rolników popyt na ziemię nie mógł być duży i wówczas Ministerstwo Reform Rolnych nie dążyło do wykonania kontyngentu parcelacyjnego.

Kiedy zaczęto realizować ustawę z 1925 roku, Ministerstwem Reform Rolnych kierowal profesor Witold Staniewicz. Nadał on reformie rolnej charakter dwuczłonowy, bowiem obok parcelacji majątków, prowadzona była komasacja ziemi w gospodarstwach chłopskich, zaś parcelację traktował on jako czynnik skłaniający mieszkańców wsi do przestrzennego uporządkowania gruntów [Staniewicz, 1928, s. 72]. Juliusz Poniatowski, późniejszy minister rolnictwa i reform rolnych, zmierzał w kierunku wytyczonym przez Witolda Staniewicza, a mianowicie: reforma miała być długotrwałym procesem parcelacji majątków i komasacji ziemi chłopskiej. W dzisiejszych publikacjach dotyczaccych II Rzeczypospolitej nazwisko Witolda Staniewicza jest pomijane.

Witold Staniewicz łączył parcelację majątków z komasacją ziemi chłopskiej, traktując całość jako proces reformowania rolnictwa. Jednakże gdy przedstawiał działalność podległego mu ministerstwa, to na pierwszym miejscu wymieniał komasację gruntów [Staniewicz, 1928, s. 72-73].

Komasacje gruntów można było prowadzić, jeśli większość rolników we wsi opowiadała się za komasacją. Podczas wielkiego kryzysu gospodarczego prace komasacyjne prowadzone przez geodetów zmalały, lecz nie zmalały tak bardzo, jak parcelacja majątków. W, najgorszym pod tym względem, roku 1934 skomasowano w kraju 353 tys. ha [Maly Rocznik Statystyczny, 1939, s. 70].

Komasacja umożliwiała rolnikom lepsze wykorzystanie ziemi, a także specjalizację, a w każdym razie przyczyniała się do odejścia od tradycyjnej trójpolówki i stosowania 
nowoczesnego płodozmianu. Jednakże nie wszyscy rolnicy opowiadali się za zmianą przestrzennego układu pół. Jeżeli w danej wsi większość rolników opowiedziała się za komasacja, to mniejszość była zdecydowanie przeciwna zmianom. Jednocześnie było wiele takich wsi, gdzie przeważali zwolennicy dotychczasowej struktury przestrzennej i tradycyjnego płodozmianu. Wynikały stąd ostre konflikty wewnątrz poszczególnych wsi, natomiast spory ogólnospołeczne na temat komasacji gruntów chłopskich w zasadzie nie występowały. Inaczej było z parcelacją majątków.

Parcelacja majątków wywoływała dyskusje ogólnospołeczne. Przedstawiciele środowiska ziemiańskiego mówili o reformie krytycznie i zdarzały się wypowiedzi całkowicie kwestionujące zasadność reformy rolnej. Władysław Glinka pisał: Tak zwana reforma rolna musi ogromnie obniżý produkcje, zabic przemyst rolny, zredukować eksport, a tym samym zniszczyć finanse państwa. To też nie chodzi tu ani o państwo, ani o naród, a chodzi pewnej liczbie osób, aby przez roźbudzenie apetytów ciemnych mas wiejskich, zapewnić sobie mandaty do sejmu i stworzyć sobie droge do władzy [Gtosy w sprawie reformy rolnej, 1925, s. 4]. Niektórzy zwolennicy parcelacji majątków proponowali radykalną wersję reformy rolnej połączonej z likwidacja ziemiaństwa. Poseł na sejm - Tadeusz Hołówka stwierdził: Ziemiaństwo by to już od dawna, a zwlaszcza terazjest klasq w Polsce szkoodliwa na wskeroś przegnita $i$ zdemoralizowanq. Ziemianstwo to przeżytek, to upiory Polski z. czasów saskich $i$ Targowicy. Ziemianstwo to drzewa, których korzenie dawno już zgnity, które jak k.łody leżq na drodze narodu polskiego i gnija i swa zgnilizna zatruwaja powietrze społeczne i polityczne w Polsce [Hołówko, 1919, s. 23]. Tadeusz Hołówko proponował, ażeby w trakcie reformy wywłaszczać bez jakiegokolwiek odszkodowania i tylko nielicznym, którzy w przeszłości zachowywali się godziwie, przyznawać rentę dożywotnią.

Ministerstwo Reform Rolnych realizowało ustawę z 1925 roku, nie ulegając naciskom ani radykalnych zwolenników, ani też zdecydowanych przeciwników parcelacji majątków. W okresie międzywojennym z parcelacji majątków przekazano nowym użytkownikom 2484 tys. ha ziemi. W efekcie powstało 154 tys. nowych gospodarstw rolnych o przeciętnej powierzchni 9,32 ha oraz 503 tys. rolników powiększyło swoje gospodarstwa [Maty Rocznike Statystyczny, 1939, s. 71]. Równolegle z tym scalono $5 \mathrm{mln}$ ha gruntów chłopskich. Czy te rezultaty reformy rolnej mogły być trwałe? To zależało od rozwoju innych działów gospodarki, a przede wszystkim od przemysłu. Jeśli rozwój sfery pozarolniczej spowodowałby odpływ ludności z rolnictwa na tyle duży, iz zmalałaby liczba ludności związanej z rolnictwem, to rezultaty reformy rolnej byłyby trwałe.

Ostateczne rezultaty reformy nie są znane, ponieważ wojna przerwała daleko nieskończony proces reformowania rolnictwa. Jednak wiadomo, co zamierzano uczynić i w jaki sposób. Istota reformy rolnej w II Rzeczypospolitej nie polegała na wspomaganiu najuboższych i dążeniu do sprawiedliwości społecznej, lecz na wzmacnianiu, gospodarstw rodzinnych w dłuższej perspektywie. Zlekceważono liczne wywody na temat ekonomicznej przewagi majątków ziemskich nad gospodarstwami rodzinnymi, a przyszłości rolnictwa upatrywano w rozwoju gospodarstw chłopskich, który mógł doprowadzić do powstania rolnictwa farmerskiego.

Warto zwrócić uwagę na zróżnicowanie normy obszarowej majątków, które nie podlegały parcelacji. Norma ta była znacznie wyższa na wschodzie niż w pozostałych re- 
jonach Polski. Tym samym uwzględniono specyfikę gospodarczą i charakter narodowościowy Kresów Wschodnich. Jednakże i na tych terenach umacniano gospodarstwa rodzinne, bowiem Kresy Wschodnie nie zostały wyłączone z reformy.

Reformę rolną okresu międzywojennego można porównać - zachowując ostrożność $-\mathrm{z}$ reformą uwłaszczeniową w zaborze pruskim w XIX wieku. Reforma uwłaszczeniowa była tam procesem trwającym prawie pół wieku i przyczyniła się do ukształtowania struktury obszarowej gospodarstw chłopskich, w której dominowały silne gospodarstwa rodzinne. Oprócz tego, została skomasowana ziemia należąca do poszczególnych właścicieli. Podobnie miało być w II Rzeczypospolitej.

\section{Jak dziś widzimy tamtą reformę}

W III Rzeczypospolitej nie ukazała się monografia o reformie rolnej II Rzeczypospolitej, którą można byłoby porównać z pracami Mieczysława Mieszczankowskiego, publikowanymi w Polsce Ludowej [Mieszczankowski, 1960; Mieszczankowski, 1983]. Tymczasem obecnie rozpowszechnione podręczniki niejednoznacznie przedstawiaja reformę rolną II Rzeczypospolitej.

Wśród aktualnych podręczników historii gospodarczej należałoby w pierwszej kolejności wymienić podręcznik Janusza Skodlarskiego, wydany w Wydawnictwie Naukowym PWN [Skodlarski, 2007]. Pobieżnie przedstawiony w nim obraz reformy umyka, a w pamięci pozostaje tylko stwierdzenie, że Pržeszkoda $w$ realizacij reformy rolnej by to ayczerpywanie sie zapasu ziemi podlegajacego reformie (...) [Skodlarski, 2007, s. 301].

Reforma rolna była dopiero w początkowym okresie realizacji, zaś tempo realizacji w latach trzydziestych zostało ograniczone $z$ powodu niewystarczającego popytu na ziemię z reformy. W skali kraju nie zabrakło ziemi, która podlegała parcelacji, natomiast zabrakło chętnych do jej nabywania, chociaż nie brakowało uprawnionych do korzystania $\mathrm{z}$ reformy.

W podręczniku Wojciecha Morawskiego pt.: Drieje gospodarcze Polski wszystkie zagadnienia reformy rolnej autor ujął w dwóch akapitach tekstu [Morawski, 2011]. W tej sytuacji czytelnik pozostał ze świadomością, że był to błahy incydent w historii Polski.

Reforma rolna zajmuje znaczące miejsce w obszernym, liczącym 750 stron, podręczniku Czesława Brzozy i Andrzeja Leona Sowy pt.: Historia Polski 1918-1945 [Brzoza, Sowa, 2006, s. 195]. Można w nim znaleźć trafne uwagi dotyczące dwóch okresów intensywnej parcelacji majątków. Były to lata 1921-1923 oraz 1926-1928. Autorzy zauważyli, że Decydujace znaczenie przez całe dwudziestolecie miata parcelacja dobrowolna, podczas której obowiazywaty ceny wolnorynkowe, a w zpriazku z.tym jej rozmiary zależaly od możliwości finansowych wsi. W latach, w których jej dochody byly wyższe lub zaciaganie posyczek stosunkowo tatwe, w rece chtopskie przechodrito nawet wiecej riemi, niž przewidywała ustawa [Brzoza, Sowa, 2006, s. 195]. Stąd parcelacja majątków była zdeterminowana popytem na ziemię.

W okresie międzywojennym parcelacja dobrowolna przeważała, ale istotnym uzupełnieniem była także parcelacja przymusowa, bowiem trzecią część ziemi przechodzącej z majątków do gospodarstw rodzinnych stanowiła ziemia z parcelacji przymusowej. 
Ustawowa regulacja reformy była gwarancja, że w sytuacji wystarczającego popytu na ziemię, 200 tys. ha z majątków co roku przejdzie do gospodarstw rodzinnych.

Ogólna ocena reformy rolnej w podręczniku Czesława Brzozy i Andrzeja Leona Sowy jest raczej negatywna. Autorzy przytoczyli dane świadczące o zmianach struktury obszarowej gospodarstw chłopskich w dwudziestoleciu międzywojennym, stwierdzili postępujące rozdrobnienie tych gospodarstw, więc skonstatowali, iż reforma rolna nie rozwiązała istniejących problemów wsi i byto to jedna z zasadnicsych prazycsyn słabości ekonomicznej panstwa [Brzoza, Sowa, 2006, s. 199].

Ekonomiści dwudziestolecia międzywojennego, którzy śledzili przebieg reformy rolnej i sytuację na wsi, byli zgodni co do tego, iż rozwiązanie kwestii agrarnej jest możliwe tylko przy intensywnym rozwoju pozarolniczych działów gospodarki. Profesor Władysław Grabski stwierdził, że w Europie Zachodniej odpływ ludności ze wsi jest większy od przyrostu naturalnego, w Polsce natomiast wzrasta ludność rolnicza i następuje rozdrobnienie gospodarstw chłopskich [Grabski, 1987, s. 121]. Profesor Wincenty Styś uważał, iż postępujące rozdrobnienie ziemi wynika z potrzeby przeżycia tych, co urodzili się na wsi i z niej nie potrafili wyjść. Poprawę sytuacji może spowodować tylko uprzemysławianie kraju. Chcac przeludnienie wsi usuná́ - pisal - trzeba prowadzić konsekwentna polityke uprzemystawiania kraju [Styś, 1934, s. 311-312]. Podobną wypowiedź można znaleźć w obszernej monografii wsi Husowa [Styś, 1947, s. 8-9]1.

Profesor Witold Staniewicz, pierwszy minister nadzorujący realizację ustawy z 1925 roku, wiedział, że ziemia gospodarstw wielkoobszarowych, nawet w całości rozparcelowana, nie wystarczy na upełnorolnienie wszystkich gospodarstw rodzinnych. Tylko migracja ludności do rozwijających się miast mogłaby rozwiązać problem przeludnienia w rolnictwie. Tymczasem reforma rolna jedynie częściowo łagodzi istniejące problemy na wsi, a przy słabym rozwoju przemysłu i niedostatecznej urbanizacji kraju skutki reformy zostaną zniwelowane. Zatem był świadomy ograniczonych możliwości reformy, lecz nie należał do zwolenników jej zaniechania. W praktyce rozszerzył zakres reformy, włączając komasację gruntów chłopskich i w ten sposób zdecydowanie wzrosła intensywność prac komasacyjnych [Mały Rocznik Statystyczny, 1939, s. 70]2. Pozostaje jedynie wątpliwość, dlaczego obecnie nazwisko Witolda Staniewicza jest konsekwentnie pomijane, o czym świadczą chociażby przytoczone wcześniej podręczniki z historii.

\section{Podsumowanie}

Wiedza o problemach rolnictwa, a także o reformie rolnej jest niezbędna do pełnego zrozumienia życia gospodarczego II Rzeczypospolitej. Intuicyjnie odczuwa się, że w pewnej mierze reforma rolna hamowała proces rozdrobnienia gospodarstw chłopskich, lecz nie można określić, w jakim stopniu reforma ograniczyła rozdrobnienie

\footnotetext{
${ }^{1}$ Wincenty Styś pisał: By przeciwdziałać ro:pyleniu struktury rolnej i oddalaniu siejej pod naciskiem przeludnienia rolniczego od gospodarczych «optimón», nie ma lepszego środka nad uprzemystowienie [Styś, 1947, s. 8-9].

2 Do roku 1926 roczne rezultaty prac komasacyjnych nie przekraczały 76 tys. ha, natomiast w latach 1926-1938 wynosily od 132 tys. do 566 tys. ha [Maly Rocznik Statystyczny, 1939, s. 70].
} 
w rolnictwie bez szczegółowych badań na podstawie materiałów empirycznych. Badania takie umożliwiłyby zarazem sformułowanie wniosków na temat znaczenia reformy dla rozwoju gospodarstw rodzinnych w rolnictwie polskim. Można tylko przypuszczać, że komasacja gruntów chłopskich miała większe znaczenie niż parcelacja majątków. Jednocześnie należy wskazać na rolę profesora Witolda Staniewicza, jako pierwszego ministra realizującego ustawę z 1925 roku. Nadszedł czas na monografię o reformie rolnej okresu międzywojennego, opartą na badaniach materiału źródłowego i wolną od ideologii marksistowskiej, jak również od poprawności politycznej.

\section{Literatura}

Brzoza Cz., Sowa A. L., 2006, Historia Polski 1918-1945, Wydawnictwo Literackie, Kraków. Gtosy w sprawie reformy rolnej, 1925, Warszawa.

Grabski W., 1987, Wybór pism, Ludowa Spółdzielnia Wydawnicza, Warszawa.

Hołówko T., 1919, Ziemianie, PPS, Warszawa.

Mały Rocznnik Statystyczny, 1939, Główny Urząd Statystyczny Rzeczypospolitej Polskiej, Warszawa.

Mieszczankowski M., 1960, Struktura agrama Polski miedsynojennej, Państwowe Wydawnictwo Naukowe, Warszawa.

Mieszczankowski M., 1983, Rolnictwo II Ržecsypospolitej, „Książka i Wiedza”, Warszawa. Morawski W., 2011, Drieje gospodarcze Polski, Wydawnictwo Difin, Warszawa.

Noniewicz Cz., 1996, Rozwó́ gospodarki chtopskiej, Wydział Ekonomiczny Filli Uniwersytetu Warszawskiego w Białymstoku, Białystok.

Okołowicz Z., 1935, Akcja scaleniowa, „Polska Gospodarcza”, 1935, z. 49.

Radwan J., 1938, Zagadnienie scalania gospodarstw wiejskich w Polsce, Towarzystwo Oświaty Rolniczej, Warszawa.

Skodlarski J., 2007, Zarys historii gospodarčej Polski, Wydawnictwo Naukowe PWN, Warszawa.

Staniewicz W., 1928, O nowy program agrarny w Polsce i jego wylkonanie, Warszawa.

Staniewicz W., 1930, Dwa lata dalszej pracy nad przeebudowa ustroju rolnego w Polsce, Towarzystwo Oświaty Rolniczej, Wilno.

Styś W., 1934, Rozdrobnienia gruntón chtopskich w bytym zaborze austriackim od roku 1787 do 1931, Nakładem Towarzystwa Naukowego, Lwów.

Styś W., 1936, Wplyw uprzemystowienia na ustrój rolny, Archiwum Towarzystwa Naukowego we Lwowie, Lwów.

Styś W., 1947, Drogipostepu gospodarczego wsi. Studium sžczegótowe na prazyktadzৃie zbiorowości próbnej wsi Husowa, Wrocławskie Towarzystwo Naukowe, Wrocław.

Ustawa z. dnia 28 grudnia 1925 roku o mykonaniu reformy rolnej, Dz. U. RP, 1926, Nr 1, poz. 1. 